\title{
非 B 非 C 肝癌の早期発見における肝臟専門医フォローアップの重要性
}

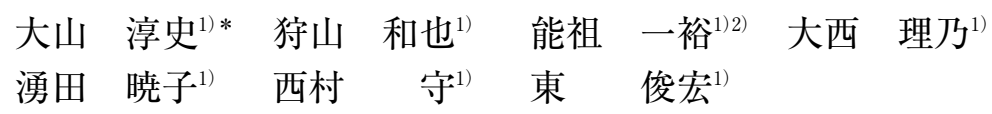

緒言：近年日本においては, 肝炎ウイルス（特にC 型肝炎）に起因する肝細胞癌が減少傾向であり, 非 B 非 C 肝癌が増加している ${ }^{1)}$. 一方非 B 非 C 肝癌では, サーベイランスアルゴリズム ${ }^{2}$ が十分に機能しておらず, 初発時に既に進行した状態で発見されるケースが認め られる。 また, 発癌のリスクファクターに関しては, 糖尿病や肥満との関連が指摘されているものの, 現時 点では完全には解明できておらず,このことがスクリー ニングの困難さにつながっていると考えられる．今回 我々は, 当院にて初回治療を行った非 B 非 C 肝癌症例 に関し, 初発までの外来通院の状況を主体として retrospective な検討を行ない,いかに高リスク群の囲い込み を行うかについて考察を行った.

対象と方法：2007 年 3 月から 2012 年 10 月までに当 院で入院加療を行った初発肝細胞癌症例のうち HBs $\mathrm{Ag}$ 抢よび HCV Ab 陰性の非 B 非 C 肝癌 67 例(肝細胞 癌 59 例, 肝内胆管癌 7 例, 細胆管細胞癌 1 例) を対象 とした. 平均観察期間は 17.3 カ月であった. アルコー ル性や自己免疫機序に基づく肝障害を主体に, 肝臟専 門医の外来を通院していた「専門医フォロー群」が 20 例 (当院では 7 例, 他院で 13 例)【Group A】, 高血圧や 糖尿病などを理由に, 定期的に肝臓専門医以外を受診 していた「一般医フォロー群」が 40 例（そのうち当院 が 8 例, 他院が 32 例)【Group B】, 初発までの外来通院 の状況に関して定期的に医師を受診していなかった「フォ ローなし群」が 7 例【Group C】の 3 群に分類し， 3 群間の背景因子, 腫瘍径, 腫瘍個数, 臨床病期, 治療 内容および予後に関してANOVA， $\chi^{2}$ 検定，Mannwhitney U 検定, Kaplan-Meier 法を用い検討を行った.

結果 : 患者背景に関して, 臨床病期は stage IVA, IVB

1）岡山市立市民病院肝疾患センター

2) 岡山大学大学院医歯薬学総合研究科分子肝臟病学

*Corresponding author: at841205@gmail.com

<受付日2013年11月19日 > <採択日2014年3月23日 >

が 19 例（28.4\%）と進行例が多く, 主腫瘍径の中央值 は $37 \mathrm{~mm}$ と大型のものが多かった. 全体の生存率は 3 年生存率 $82 \%, 5$ 年 $73 \%$ であった. 今回検討した 3 群では, 各群とも発癌因子と考えられた原疾患はアル コール性肝障害, NASH, AIHの順であった。なお飲 酒に伴う総エタノール摂取量が $80 \mathrm{~g}$ 以上の症例をアル コール性と定義, NASH 及び AIH 群は当院もしくは他 院にて生検で組織学的に診断された症例のみを定義し た. 高血圧, 糖尿病, アルコール性肝障害といった併 存疾患の有無で有意差は認めなかったが, 一般医フォ ロー群の 40 人中, 15 人が糖尿病を主訴に通院する患者 であり, 半数以上に肝機能異常が認められていた. 年 齢では一般医フォロー群と比較し専門医フォロー群が 有意に低かった.

腫瘍径, 腫瘍個数ともに A 群で有意に小さく, 病期 分類に関しても stage I/II が $75 \%$ を占め有意に早期に 発見されていた． A 群においてはミラノ基準内での診 断が有意に高率で, 早期発見に貢献していた(寄与率 : 3.88, $\mathrm{P}<0.01)$. 腫瘍マーカーは DCP のみ A 群で有意 に低值であった $(\mathrm{P}=0.08)$. 治療は $\mathrm{A}$ 群のほとんどで 局所治療が選択されていたのに対し，C群では Chemo therapy, BSC を選択された症例が多く認められた(Table). 3 群間の生存率は Fig.に示した. A 群で 5 年生存 率は $92 \%$ と有意に専門医フォロー群が予後良好であっ た.

考察 : 今回の検討で初発非 B 非 C 肝癌発症者の約 9 割の症例が定期通院中の患者であった．また全ての群 において発癌因子はアルコールの症例が多く, 一般医 フォロー群においても, 肝障害を指摘されていた症例 が半数以上を占めていた。肝臓専門医フォロー中の患 者は半年ごとの腹部超音波検査が定期的に行われてお り, 同群の発癌では $75 \%$ が stage II までに診断されて いた。この早期発見により根治的治療が選択され，予 後改善に寄与していたと考えられた。一方で，一般医 フォロー中の患者は半数以上が stage III から IV の進行 癌で発見されていた. 非 B 非 C 肝癌を早期発見するた 
Table Examination of prognostic factor in 67 outpatients

\begin{tabular}{lrrrr}
\hline & Group A & Group B & Group C & P value \\
\hline Age (years, median) & 63.8 & 72.5 & 68.4 & $<0.01$ \\
Sex (male/female) & $12 / 8$ & $31 / 9$ & $6 / 1$ & 0.25 \\
Child-pugh score (A/B/C) & $8 / 11 / 1$ & $27 / 10 / 3$ & $5 / 1 / 1$ & 0.15 \\
AFP (mg/dL, range) & $1.8-22.6$ & $2.1-120840$ & $2.1-15746$ & 0.67 \\
DCP (mg/dL, range) & $15-403$ & $16-75000$ & $13-41400$ & 0.08 \\
Etiology (ALD/NASH/Auto immune/unknown) & $12 / 5 / 3 / 0$ & $23 / 13 / 2 / 2$ & $4 / 3 / 0 / 0$ & 0.68 \\
Stage ( II/II/IV) & $15 / 5 / 0$ & $18 / 8 / 14$ & $2 / 0 / 5$ & 0.02 \\
Tumor number (solitary/multiple) & $8 / 12$ & $18 / 22$ & $2 / 5$ & 0.02 \\
Tumor diameter (mm, median, range) & $17:[10-47]$ & $53:[21-100]$ & $46:[12-150]$ & $<0.01$ \\
Treatment (RFA or ope/TACE/Chemo therapy or BSC) & $19 / 0 / 1$ & $27 / 3 / 10$ & $2 / 0 / 5$ & 0.11 \\
\hline
\end{tabular}

$\mathrm{ALD}=$ Alcoholic liver disease $\mathrm{NASH}=$ Non-alcoholic steatohepatitis $\mathrm{RFA}=$ radiofrequency ablation $\mathrm{TACE}=$ trans catheter arterial chemo embolization $\quad \mathrm{BSC}=$ best suppotive care

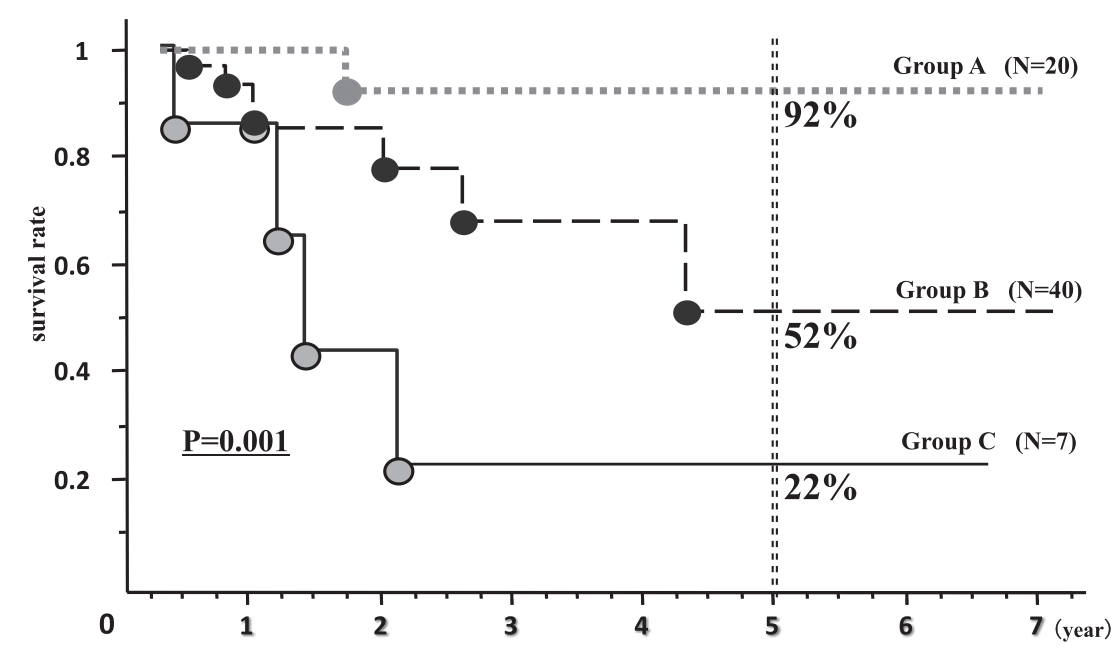

Fig. Comparison of survival rate among outpatients of Board Certified Hepatologist, those of uncertified physician and patients without regular check up by doctors

めにはアルコール性肝障害, NASH などのリスクを有 する患者をいかに囲い込んでいくかが重要な課題であ る. 非 B 非 C 肝癌の危険因子としては, アルコール性 肝障害に加え糖尿病が重要視されている. 肝癌発症の リスクが糖尿病合併で 2-7 倍 ${ }^{3)}$, 飲酒では 2-7 倍 ${ }^{4)}$, 肝 機能異常を有することで 9 倍となる報告5)があり, これ らリスク因子を有する患者は肝癌の高リスク群として フォローアップする必要がある。また, 男性や高齢な ども肝癌の追加リスク因子であり ${ }^{2)}$, 今後一般医に対し 肝臓専門医が啓発していくことが重要であると考えら
れた。さらに一般医と専門医とをつなぐ病診連携等を 利用して相互にサーベイランスを結び付けていくこと で, 非 B 非 C 肝癌の診断時高度進行例を減少させ予後 改善につながると考えられた.

結語 : 肝臓専門医によるアルコール性肝障害, NASH 等の外来経過観察は, NBNC 肝癌の早期発見による予 後の改善に貢献していた.

本論文の要旨は第 49 回日本肝癌研究会 (2013 年, 東京) にて報告した. 
索引用語： $\mathrm{NBNC}$ 肝癌, 肝臟専門医, 外来

文献 : 1） Koike Y, Shiratori Y, Sato S, et al. Hepatology 2000; 32: 1216-1223 2) 日本肝癌研究会. 第 17 回全国原発性肝癌追跡調査報告. 日本肝癌研 究 会事務局, 京都 3) Hara M, Sasaki S, Tsugane S, et al. IARC Sci Publ 2002; 156: 165-168

4) Inoue $M$, Iwasaki $M$, Otani $T$, et al. Arch Intern Med 2006; 25: 1871-1877 5) Ishiguro S, Inoue M, Tanaka Y, et al. Eur J Cancer Prev 2009; 18: 2632

本論文内容に関連する著者の利益相反：なし

\section{英文要旨}

Contribution of hepatologists for the early detection of nonB-nonC HCC

Atsushi Ohyama ${ }^{1)}$, Kazuya Kariyama ${ }^{1)}$, Kazuhiro Nouso ${ }^{122}$, Ayano Oonishi' ${ }^{1)}$, Akiko Wakuta ${ }^{1)}$, Mamoru Nishimura ${ }^{1)}$, Toshihiro Higashi ${ }^{1)}$

Many nonB-nonC HCCs were found at an advanced stage because of the difficulties of surveillance. We examined the correlation between the follow-up status of 67 nonB-nonC HCCs and their clinical features. HCCs were found earlier when the patients were followed up at outpatients of Board Certified Hepatologist than in cases without regular check up by doctors or in cases followed up by uncertified physicians. We speculated that regular surveillance of HCC was necessary when the patients had the risk of HCC (NASH, alcoholic liver diseases et al.) regardless of their main diseases to achieve the early detection and to improve the prognosis of the patients with nonB-nonC HCC.

Key words: nonB-nonC liver cancer, hepatologist, outpatient

Kanzo 2014; 55: 284-286

1) Department of Liver Disease Center, Okayama City Hospital

2) Department of Molecular Hepatology, Dentistry and Pharmaceutical Sciences, Okayama University Graduate School of Medicine

*Corresponding author: at841205@gmail.com 